\title{
Effect of Applying Cold Gel Pack to the Sternum Region on the Postoperative Pain after Open-Heart Surgery
}

\author{
Kıvan Çevik ${ }^{1}$, Serpil İnce ${ }^{2}$, Sevgi Pakiş Çetin ${ }^{1 *}$, Ömer Tetik ${ }^{3}$ \\ ${ }^{1}$ Manisa Celal Bayar Üniversitesi Sağlık Bilimleri Fakültesi, Hemşirelik Esasları Anabilim Dalı, Manisa, Türkiye. \\ ${ }^{2}$ Akdeniz Üniversitesi Hemşirelik Fakültesi, Hemşirelik Esasları Anabilim Dalı, Antalya, Türkiye. \\ ${ }^{3}$ Manisa Celal Bayar Üniversitesi, Kalp Damar Cerrahisi Anabilim Dalı, Manisa, Türkiye
}

e-mail: kivancevikk@gmail.com, sevgis210188@hotmail.com,serpildogan@akdeniz.edu.tr,omer.tetik@.cbu.edu.tr Orcid: 0000-0002-0556-8012

Orcid: 0000-0002-2160-8440

Orcid: 0000-0001-8330-3493

Orcid: 0000-0002-6683-5663

*Sorumlu Yazar / Corresponding Author: Sevgi Pakiş Çetin

Gönderim Tarihi / Received: 10.10.2019

Kabul Tarihi / Accepted: 24.03.2020

DOI: $10.34087 /$ cbusbed631665

\begin{abstract}
Amaç: Bu çalışma açık kalp ameliyatı sonrasında sternum bölgesine uygulanan soğuk uygulamanın, derin solunum ve öksürük uygulaması sırasında oluşan ağrı üzerine etkisini incelemek amacıyla yapıldı.

Gereç ve Yöntem: Çalışmanın örneklemini 46 kişi oluşturdu. Çalışma verileri toplanırken, araştırmacı tarafından ilgili literatür doğrultusunda hazırlanan hastalara ilişkin sosyodemografik özelliklerin yer aldığı "Hasta Tanıtım Formu", hastanın ağrı şiddetini değerlendirmek için "Visüel Analog Skala-VAS", derin solunum ve öksürük egzersizleri öncesinde ve sonrasında hastanın ağrı seviyelerini kaydetmek için "Ağrı İzlem Formu” kullanıldı. Derin solunum ve öksürük egzersizleri sonrasında ağrı seviyeleri ölçüldü. Girişim, kontrol ve plasebo grupları arasında karşıllaştırıld1.

Bulgular: Gruplar arası analiz; girişim, kontrol ve plasebo grupları arasında işlem öncesi ve işlem sonrası elde edilen ortalama VAS skorları açısından istatistiksel olarak anlamlı bir fark olmadığını gösterdi. Ancak girişim grubunda; işlem öncesi ve işlem sonrası elde edilen ortalama VAS skorları açısından istatistiksel olarak anlamlı bir fark saptandı. Sonuç: $\mathrm{Bu}$ çalışmanın sonucu, soğuk uygulamanın açık kalp ameliyatı olan hastalarda derin solunum ve öksürükle ilişkili sternal insizyon ağrı yönetiminde etkili bir yöntem olduğunu gösterdi.
\end{abstract}

Anahtar Kelimeler: Postoperatif Ağrı, Nefes Egzersizleri, Kardiyak Cerrahi, Cerrahi Sonrası Hemşirelik.

\begin{abstract}
Aim: The present study was performed at investigating the effects of cold gel pack applied to the sternum on the pain associated with deep breathing and coughing after open-heart surgery.

Materials and Methods: The study sample included 46 participants. While the study data were collected, the "Patient Information Form" prepared by the researcher based on the pertinent literature was used to question the sociodemographic characteristics of the patients, the "Visual Analogue Scale-VAS" was used to assess the severity of the patient's pain, and the "Pain Monitoring Form" was used to record the patient's pain associated with deep breathing and coughing exercises before and after cold gel pack application. Pain scores after deep breathing and coughing were measured and compared warm (room temperature) (placebo) gel pack, with (intervention) and without (control) the gel pack.
\end{abstract}

Results: The intergroup analysis showed that the difference between the experimental, control and placebo groups in terms of their mean VAS scores obtained before the procedure and after the procedure was not statistically significant. But in the experimental group; in terms of their mean VAS scores obtained before the procedure and after the procedure was determined statistically significant.

Conclusions: The results of this study showed that cold therapy is an effective method for management of sternal incision pain associated with coughing and deep breathing in open heart surgery patients.

Key words: Postoperative Pain, Breathing Exercises, Cardiac Surgery, Post-Surgical Nursing. 


\section{Introduction}

Every year millions of patients undergo surgical intervention and $\% 80$ of these patients experience postoperative pain [1]. Due to the opening of the sternum in open heart surgery, the soft tissues and nerves in the chest wall are severely damaged and may cause chest wall discomfort after the surgery [2]. In addition, patients who are stayed in the critical care unit for a period of postoperative 1 to 3 days participates in numerous procedures such as endotracheal suctioning, turning, coughing, breathing, and chest tube removal, activities which are perceived to be the most painful routine procedures and treatment interventions during this time [3-5].

Acute postoperative pain was severe in the majority of patients after cardiac surgery [6,7]. Untreated postoperative pain can cause chronic pain problems. After open-heart surgery, chronic post sternotomy pain incidence is reported varies from 21 to $60 \%$ at $1-3$ years according to various studies [2,7-12]. Chronic postsurgical pain affecting the quality of life and has serious economic results $[13,14]$. It is vital that the patient maintain postoperative pain management at optimal level in order to increase patient satisfaction, reduce the postoperative complications and duration of hospitalization in open heart surgery $[2,3,15]$. Insufficient pain management bring about patients to complications such as hypoxemia, atelectasis, pneumonia and deep vein thrombosis because of mucous plugging and their insufficiency to cough, mobilize effectively [3,6,15-18]. Furthermore, unrelieved postoperative pain may have a negative psychological effect and impede postoperative recovery [3]. Incisional pain can be managed with both pharmacologic and nonpharmacologic methods [19]. Nonpharmacological methods are advantageous because no chemical agents are given to the body and they can be applied by the nurses [20]. Cold therapy is an effective, simple, cheap and safe one of the nonpharmacologic methods to reduce pain with few complications or no side effects [15]. Cold may result in enhanced activa $\neg$ tion of supraspinal mechanisms, raising the body's overall pain threshold $[21,22]$.

This study was aimed at investigating the effects of cold gel pack applied to the sternum on the pain caused by deep breathing and coughing after open-heart surgery.

\section{Materials and Methods}

This study was a randomized controlled trial which was conducted in the cardiac surgery intensive care unit (ICU) at a university hospital in Turkey between July 2015 to September 2016. In order to reduce variability among patients, only patients with coronary artery bypass grafts (CABG) surgery were taken and cold gel package was performed on the first postoperative day.

\subsection{Participants}

The following inclusion criteria were applied: aged over 18 years, patients scheduled to coronary artery bypass graft (CABG) surgery with median sternotomy, able to understand and speak Turkish, hadnot received mechanical ventilation support, oriented to place and time, able to report pain, patients undergoing their first open heart surgery and willing to give written informed consent. Patients who had mechanically ventilated patients, contraindication to cold therapy use (Raynaud's disease), diabetic patients, could not understand the use of a pain scale, postoperative complications such as infection, bleeding, uncontrolled atrial fibrillation were excluded from the study.

\subsection{Ethical consideration}

Before commencing the research, written permission was obtained from Ethics Committee (consent no 06/2014). Verbal and written informed consent was obtained from each of the patients for the present study.

\subsection{Data Collection}

While the study data were collected, the "patient information form" prepared by the researcher based on the pertinent literature was used to question the sociodemographic characteristics of the patients, the "Visual Analogue Scale-VAS" was used to assess the severity of the patient's pain, and the "Pain Monitoring Form" was used to record the patient's pain associated with deep breathing and coughing exercises before and after cold gel pack application.

\subsection{Procedures}

A simple randomization method was used to select patients for groups for the study to prevent conscious or unconscious manipulation in selection. The same postoperative analgesic method was used for all patients, and they all received the same type of analgesics. But we also applied cold gel pack to the experimental group. Patients who conformed to the rules for admission to the study were assigned to one of three groups:

Intervention Group: Cold application group.

Control Group: Group without application.

Placebo Group: Warm application (room temperature) group.

\subsection{Cold Gel Pack Application}

The use of cold packs in the form of silica gel packs is the most commonly used method of cold application in clinics. The special silica gel soaked in water in a soft rubber envelope can be stored in various sizes and shapes special tanks [23-25]. We were used weighed 110 grams and measured $13 \times 13 \mathrm{~cm}$, flexible cold gel pack. They were kept in the freezer on the patient service unit. The gel packs need approximately two hour of freezing before the temperature is low enough to be suitable for use and then were removed from the freezer and placed in a cotton bag. Placebo pack were kept at room temperature at $18-22^{\circ} \mathrm{C}$. The steps in the applications to patients included in the study were as follows:

Intervention Group/ Cold Application Group: 
After deep breathing and coughing exercise, VAS was used before cold application to measure and record the patient's starting pain intensity (VAS-1). After the measurement, the cold gel pack placed in a cotton bag. The timer was activated for $15 \mathrm{~min}$ and gel pack was used over the sternal wound dressing. At the end of 15 minutes, the researcher was made deep breathing and coughing exercises. After the exercises, VAS was used to measure and record the patient's pain intensity (VAS-2).

\section{Control Group/ Group Without Application:}

After deep breathing and coughing exercise, VAS was used to measure and record the patient's starting pain intensity (VAS-1). About 15 minutes after the measurement, the researcher was made deep breathing and coughing exercises. After the exercises, VAS was used to measure and record the patient's pain intensity (VAS-2)

Placebo Group/ Warm Application Group:

After deep breathing and coughing exercise, VAS was used before warm gel pack application to measure and record the patient's starting pain intensity (VAS-1). After the measurement, the warm gel packs, which was at room temperature, placed in a cotton bag. The timer was activated for 15 min and gel pack was used over the sternal wound dressing. At the end of 15 minutes, the researcher was made deep breathing and coughing exercises. After the exercises, VAS was used to measure and record the patient's pain intensity (VAS-2).

\subsection{Statistical Analysis}

The data obtained from the study were analysed on a computer using the Wilcoxon test, Chi-square test and Kruskal-Wallis variance analysis in the Statistical Package for Social Science.

\section{Results}

Table 1. Demographic characteristics of patients

There were 46 patients recruited for this study from after cardiac surgery ICU, and no side effects or complications due to the cold therapy via gel pack were reported. The results showed that there were no statistically significant differences in the demographic characteristics of the patients in the three groups ( $\mathrm{p}>0.05$, Table 1). The mean age of the patients was $60.73 \pm 1.08$ (min. 39, max. 81). Of them, $58.7 \%$ were male, $91.3 \%$ were married and $60.9 \%$ were primary school graduates, $82.6 \%$ had two chest tubes (Table 1).

Table 2. Comparison of mean pain scores before and after cold gel pack application in three groups

The mean VAS scores before and after the cold gel pack applications were $6.93 \pm 2.40$ and $4.26 \pm 2.63$ in the experimental group, $5.68 \pm 2.52$ and $4.86 \pm 2.52$ in the control group and $5.06 \pm 2.12$ and $4.86 \pm 2.58$ in the placebo group, respectively. The intergroup analysis showed that the difference between the experimental, control and placebo groups in terms of their mean VAS scores obtained before the procedure $(\mathrm{p}=.102)$ and after the procedure $(\mathrm{p}=.378)$ was not statistically significant ( $p>0.05$ ). But in the experimental group; in terms of their mean VAS scores obtained before the procedure and after the procedure was statistically significant $(\mathrm{p}=.001$, Table 2).

Table 1. Demographic Characteristics of Patients

\begin{tabular}{|c|c|c|c|c|c|c|c|c|c|}
\hline & \multicolumn{2}{|c|}{$\begin{array}{l}\text { Intervention } \\
(\mathbf{n}=\mathbf{1 5})\end{array}$} & \multicolumn{2}{|c|}{ Control (n=16) } & \multicolumn{2}{|c|}{$\begin{array}{l}\begin{array}{l}\text { Placebo } \\
(n=15)\end{array} \\
\left(\begin{array}{l}\text { (n) }\end{array}\right.\end{array}$} & \multicolumn{2}{|c|}{$\begin{array}{l}\text { Total } \\
(\mathrm{n}=46)\end{array}$} & \multirow[t]{2}{*}{ Test } \\
\hline & n & $(\%)$ & $\mathbf{n}$ & $(\%)$ & n & $(\%)$ & $\mathrm{n}$ & $(\%)$ & \\
\hline \multicolumn{10}{|l|}{ Gender } \\
\hline Female & 8 & 53.3 & 7 & 43.8 & 4 & 26.7 & 19 & 41.3 & \multirow{3}{*}{$\begin{array}{l}X^{2}=2.260 \\
p=0.323\end{array}$} \\
\hline Male & 7 & 46.7 & 9 & 56.2 & 11 & 73.3 & 27 & 58.7 & \\
\hline Mean age & \multicolumn{2}{|c|}{$63.40 \pm 12.06$} & \multicolumn{2}{|c|}{$59.75 \pm 9.34$} & \multicolumn{2}{|c|}{$59.13 \pm 11.33$} & \multicolumn{2}{|c|}{$60.73 \pm 1.08$} & \\
\hline \multicolumn{10}{|l|}{ Age } \\
\hline $39-49$ & 2 & 28.6 & 2 & 28.6 & 3 & 42.9 & 7 & 15.2 & \multirow{4}{*}{$\begin{array}{l}X^{2}=5.260 \\
p=0.511\end{array}$} \\
\hline $50-60$ & 3 & 17.6 & 8 & 47.1 & 6 & 35.3 & 17 & 37.0 & \\
\hline $61-70$ & 6 & 50.0 & 2 & 16.7 & 4 & 33.3 & 12 & 26.1 & \\
\hline 71-81 & 4 & 40.0 & 4 & 40.0 & 2 & 20.0 & 10 & 21.7 & \\
\hline \multicolumn{10}{|l|}{ Marital status } \\
\hline Married & 12 & 80.0 & 16 & 100 & 14 & 93.3 & 19 & 91.3 & \multirow{2}{*}{$\begin{array}{l}X^{2}=4.016 \\
p=0.134\end{array}$} \\
\hline Single & 3 & 20.0 & - & - & 1 & 6.7 & 27 & 8.7 & \\
\hline \multicolumn{10}{|c|}{ Educational status } \\
\hline Illiterate & 3 & 20.0 & 2 & 12.5 & 3 & 20.0 & 8 & 17.4 & \multirow{4}{*}{$\begin{array}{l}X^{2}=8.182 \\
p=0.225\end{array}$} \\
\hline Primary school & 6 & 40.0 & 12 & 75.0 & 10 & 66.7 & 28 & 60.9 & \\
\hline High school & 4 & 26.7 & - & - & 2 & 13.3 & 6 & 13.0 & \\
\hline License & 2 & 13.3 & 2 & 12.5 & - & - & 4 & 8.7 & \\
\hline \multicolumn{10}{|c|}{ Number of chest tube } \\
\hline 1 & 2 & 13.3 & 1 & 6.2 & - & - & 3 & 6.5 & \multirow{3}{*}{$\begin{array}{l}X^{2}=2.258 \\
p=0.323\end{array}$} \\
\hline 2 & 11 & 73.3 & 13 & 81.2 & 14 & 93.3 & 38 & 82.6 & \\
\hline 3 & 2 & 13.3 & 2 & 12.5 & 1 & 6.7 & 5 & 10.9 & \\
\hline
\end{tabular}


Table 2. VAS Score Comparisons of the Patients from the Experimental, Control and Placebo Groups

\begin{tabular}{|l|c|c|c|}
\hline & $\begin{array}{c}\text { Before } \\
\text { (VAS-1) } \\
\mathbf{X} \pm \mathbf{S D}\end{array}$ & $\begin{array}{c}\text { After } \\
(\mathbf{V A S}-2) \\
\mathbf{X} \pm \mathbf{S D}\end{array}$ & Test \\
\hline The group started with gel pack & $6.93 \pm 2.40$ & $4.26 \pm 2.63$ & $\begin{array}{c}\mathrm{Z}=-3.192, \\
\mathrm{p}=0.001 *\end{array}$ \\
\hline The group started without gel pack & $5.68 \pm 2.52$ & $4.86 \pm 2.52$ & $\begin{array}{c}\mathrm{Z}=0.000, \\
\mathrm{p}=1.000\end{array}$ \\
\hline The group started with warm gel pack & $5.06 \pm 2.12$ & $4.86 \pm 2.58$ & $\begin{array}{c}\mathrm{Z}=-0.535, \\
\mathrm{p}=0.593\end{array}$ \\
\hline $\mathrm{KW}$ & 4.572 & 1.948 & \\
$\mathrm{p}$ & 0.102 & 0.378 & \\
\hline
\end{tabular}

SD: Standart Deviation, Z: Wilcoxan 2 Related Samples ${ }^{*} \mathrm{p}<0.05, \mathrm{KW}$ : Kruskal-Wallis Variance Analysis

\section{Discussion}

Sternal incision pain is the most common complaint after these surgeries $[15,19]$. Patients who underwent open heart surgeries report having most severe pain during deep breathing and coughing then pain at rest [6,26]. Especially deep breathing and coughing exercise is one of the most painful activities. Deep breathing and coughing exercise are important in the prevention of respiratory complications such as hypoxemia, atelectasis, pneumonia. But, patient sare not likely to do this exercise if they are uncomfortable, or do not have strategies to control the break through pain [19]. We used cold gel pack in order to relieve pain.

In this study, pain was significantly decreased with the use of cold gel packs. Pain scores after cold application were lower with gel pack compared to before cold application. Our study showed that the cold gel pack application is an effective method for management of sternal incision pain associated with deep breathing and coughing in open heart surgery patients. Four studies previously investigated the effect of cold application for reducing the pain related to deep breathing and coughing. In a randomized crossover design, Chailler et al. (2010) evaluated the level of sternal pain after deep breathing and coughing in four stages [19]. A significant reduction in pain scores between pre- and post-application of the gel pack was found. Khalkhali et al. (2014) and Pishkar Mofrad et al. (2016) was performed on 50 patients undergoing $\mathrm{CABG}$, reporting similar results regarding the reduction of sternal pain after cold therapy [15, 28]. Another study by Ebrahimi-Rigi et al. (2016) reported that cold therapy reduced pain relating to deep breathing and coughing in patient undergoing coronary artery bypass grafting. The findings of the present study are similar to the results of aforementioned studies [27]. Thus, the cold therapy may be an effective approach that can be used for relieving pain associated with coughing and deep breathing in postsurgical patients.

Similar results were obtained with cold therapy in various conditions such as chest tube removal, soft tissue injuries and postoperative [20, 25, 29-33]. In another research, Hasanzadeh et al. (2016) investigated the effects of cold therapy and inhalation of lavender oil on the level of pain and anxiety during the removal of chest tube in patients in the cardiac intensive care unit undergoing CABG. According to the results, cold application and aromatherapy helped to the significant reduction of pain and anxiety in the patients [34].

As a limitation, this study was performed on 46 individuals due to the small number of cases in the hospital and was limited to patients who underwent CABG surgery. While these inclusion criteria increased the homogeneity of the study population, it made the generalizability of the findings difficult.

\section{Conclusions}

Cold gel pack application was effective for decreasing incisional pain associated with deep breathing and coughing after open heart surgery. It is very important to emphasize that cold application is an independent nursing intervention in the control of pain. Another important point is; it should be noted that pain management depends on effective communication and collaboration of the multidisciplinary health care professionals. In this respect, it is considered that studies are need involving multidisciplinary approaches. Other non-pharmacological methods such as cold application are recommended as complementary therapy with pharmacological methods and investigate for more information about the effects of different post-surgical periods, and ways of cold application with a broader sampling base. Future studies could also perform the same design, but after removing the chest tube to increase its reliability. Because pain may also depend on the chest tube.

\section{Funding}

This research received no specific Grant from any funding agency in the public, commercial, or not-forprofit sectors.

\section{Acknowledgements}

We thank all the patients who patiently supporting to participate during the study.

\section{Conflicts of Interest}

The authors declare that there is no conflict of interest. 
The present study has several limitations. The major limitation is that we did not exclude the patients who had also a co-diagnosis of depression which might have biased the results. One might argue that schizophrenic patients may be more sensitive towards criticism, and depressed patients may be more sensitive towards emotional overinvolvement, or respectively, that key relatives of schizophrenic patients behave in a more critical manner, while those of depressed patients are more emotionally overinvolved. Any psychotropic medications and dosages were not controlled for the caregivers. Also, we did not measure the severity of depression in caregivers, since we excluded the relatives with a current diagnosis of major depression and any anxiety disorder.

\section{Refrences}

1. Samuels, J.G, Fetzer, S, Pain management documentation quality as a reflection of nurses clinical judgment, Journal of Nursing Care Quality, 2009, 24(3), 223-231.

2.Leegaard, M, Naden, D, Fagermoen, M.S, Postoperative pain and self-management: women's experiences after cardiac surgery, Journal of Advanced Nursing, 2008, 63(5), 476-485

3. Yorke, J, Mclean, B, Wallis, M, CardioThor, G.D, Cert, C, McLean, B, Cert, G, Patients' perceptions of pain management after cardiac surgery in an australian critical care unit, Heart Lung. 2004, 33(1), 33-41.

4. Gelinas, C. Management of pain in cardiac surgery ICU patients: Have we improved over time? Intensive and Critical Care Nursing, 2007, 23(5), 298-303.

5. Boitor, M, Martorella, G, Laizner, A.M, Maheu, C, Gélinas, C. The effectiveness of hand massage on pain in critically ill patients after cardiac surgery: A randomized controlled trial protocol, JMIR Research Protocols, 2016, 5(4), e203.

6. Milgrom, L.B, Brooks, J.A, Qi, R, Bunnell, K, Wuestfeld, S, Beckman, D, Pain levels experienced with activities after cardiac surgery, American Journal of Critical Care, 2004, 13(2), 116-125.

7.Lahtinen, P, Kokki, H, Hynynen, M, Pain after cardiac surgery a prospective cohort study of 1-year incidence and intensity, Anesthesiology, 2006, 105(4), 794-800.

8. Kalso, E, Mennander, S, Tasmuth, T, Nilsson, E, Chronic poststernotomy pain, Acta Anaesthesiologica Scandinavica, 2001, 45(8), 935-939.

9. Eisenberg, E, Pultorak, Y, Pud, D, Bar-El, Y, Prevalence and characteristics of post coronary artery bypass graft surgery pain (PCP), Pain, 2001, 92(1-2), 11-17.

10. Meyerson, J, Thelin, S, Gordh, T, Karlsten, R, The incidence of chronic post-sternotomy pain after cardiac surgery: A prospective study, Acta Anaesthesiologica Scandinavica, 2001, 45(8), 940-944.

11. Bruce, J, Drury, N, Poobalan, A.S, Jeffrey, R.R, Smith, W.C, Chambers, W.A, The prevalence of chronic chest and leg pain following cardiac surgery: A historical cohort study, Pain, 2003 , 104(1-2), 265-73.

12. Bjørnnes, A.K, Parry, M, Lie, I, Watt-Watson, J, Rustøen, T, Stubhaug, A, Leegaard, M, The impact of an educational pain management booklet intervention on postoperative pain control after cardiac surgery, European Journal of Cardiovascular Nursing, 2017, 16(1), 18-27.

13. Gálvez, R, Marsal, C, Vidal, J, Ruiz, M, Rejas, J, Cross-sectional evaluation of patient functioning and health-related quality of life in patients with neuropathic pain under standard care conditions, European Journal of Pain, 2007, 11(3), 244-255.

14. Akkaya, T, Özkan, D, Chronic post-surgical pain, Ağrı, 2009, 21(1), 1-9.

15. Khalkhali, H, Tanha, Z.E, Feizi, A, Ardabili, S.S, Effect of applying cold gel pack on the pain associated with deep breathing and coughing after open heart surgery, Iranian Journal of Nursing and Midwifery Research, 2014, 19(6), 545-549.

16. Tetik, Ö, İslamoğlu, F, Ayan, E, Duran, M, Buket, S, Çekirdekçi, $\mathrm{A}$, Intermittent infusion of $0.25 \%$ bupivacaine through an intrapleural catheter for post-thoracotomy pain relief, The Annals of Thoracic Surgery, 2004, 77(1), 284-288.
17. Bell, L, Duffy, A, Pain assessment and management in surgical nursing: A literature review, British Journal of Nursing, 2009, 18(3), 153-156.

18. Bjørnnes, A.K, Rustøen, T, Lie, I, Watt-Watson, J, Leegaard, M, Pain characteristics and analgesic intake before and following cardiac surgery, European Journal of Cardiovascular Nursing, 2016, 15(1), 47-54.

19. Chailler, M, Ellis, J, Stolarik, A, Woodend, K, Cold therapy for the management of pain associated with deep breathing and coughing post-cardiac surgery, Canadian Journal of Cardiovascular Nursing, 2010, 20(2), 18-24.

20. Ertuğ, N, Ulker, S, The effect of cold application on pain due to chest tube removal, Journal of Clinical Nursing, 2012, 21(5-6), 784790.

21. Nahra, H, Plaghki, L, Innocuous skin cooling modulates perception and neurophysiological correlates of brief $\mathrm{CO} 2$ laser stimuli in humans, European Journal of Pain, 2005, 9(5), 521-530.

22. Baxter, A.L, Cohen, L.L, McElvery, H.L, Lawson, M.L, Von Baeyer, C.L, An integration of vibration and cold relieves venipuncture pain a pediatric emergency department, Pediatric Emergency Care, 2011, 27(12), 1151-1156.

23. On, Y.A, Ağrı tedavisinde soğuk uygulamalar, Ağrı, 2006, 18(2), 5-14.

24. Kazan, E.E, Soğuk uygulamalar ve hemşirelik bakımı, Hacettepe Üniversitesi Sağlık Bilimleri Fakültesi Hemşirelik Dergisi, 2011, 73 82

25. Kol, E, Erdogan, A, Karsl1, B, Erbil, N. Evaluation of the outcomes of ice application for the control of pain associated with chest tube irritation. Pain Management Nursing, 2013, 14(1), 29-35.

26. Çevik, K, Zaybak, A, Açık kalp ameliyatı sonrasında yapılan egzersizlerin ağrıya etkisi, Anadolu Hemșirelik ve Sağlık Bilimleri Dergisi, 2011, 14(4), 54-59.

27. Ebrahimi-Rigi, H, Feizi, A, Abdollahimohammad, A, EbrahimiRigi, Z, Salehi-Ardabili, S, Effect of cold therapy on the pain of deep-breathing and coughing in patients after coronary artery bypass grafting, Der Pharmacia Lettre, 2016, 8(10), 201-205.

28. Pishkar Mofrad, Z, Navidian, A, Ahmadabadi, C.A, Aliahmadi, E, Effects of localized cryotherapy on the severity of thoracic pain in patients undergoing coronary artery bypass grafting, MedicalSurgical Nursing Journal, 2016, 5(1), 22-27.

29. Airaksinen, O.V, Kyrklund, N, Latvala, K, Kouri, J.P, Grönblad, M, Kolari, P, Efficacy of cold gel for soft tissue injuries: A prospective randomized double-blinded trial, The American Journal of Sports Medicine, 2003, 31(5), 680-684.

30. Koç, M, Tez, M, Yoldas, Ö, Dizen, H, Göçmen, E. Cooling for the reduction of postoperative pain: Prospective randomized study, Hernia. 2006, 10(2), 184-186.

31. Chou, S.Y, Liu, H.E, Comparison of effectiveness between moist and dry cryotherapy in reducing discomfort after orthognathic surgery, Journal of Clinical Nursing, 2008, 17(13), 1735-1741.

32. Demir, Y, Khorshid, L, The effect of cold application in combination with standard analgesic administration on pain and anxiety during chest tube removal: A single- blinded, randomized, double-controlled study, Pain Management Nursing, 2010, 11(3), 186-196.

33. Payami, M.B, Daryei, N, Mousavinasab, N, Nourizade, E, Effect of cold application in combination with Indomethacin suppository on chest tube removal pain in patients undergoing open heart surgery, Iranian Journal of Nursing and Midwifery Research, 2014, 19(1), 7781

34. Hasanzadeh, F, Kashouk, N.M, Amini, S, Asili, J, Emami, S.A Vashani, H.B, Sahebkar, A, The effect of cold application and lavender oil inhalation in cardiac surgery patients undergoing chest tube removal, Excli Journal, 2016, 15, 64-74.

http://edergi.cbu.edu.tr/ojs/index.php/cbusbed isimli yazarın CBU-SBED başlıklı eseri bu Creative Commons Alıntı-Gayriticari4.0 Uluslararası Lisansı ile lisanslanmıştır.

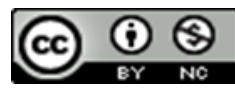

